\title{
ESTIMATION OF SECTORAL PRICES IN THE BNL ENERGY INPUT-OUTPUT MODEL
}

Raymond G. Tessmer, JR., Paul Groncki, and Glenn W. Boyce, JR.
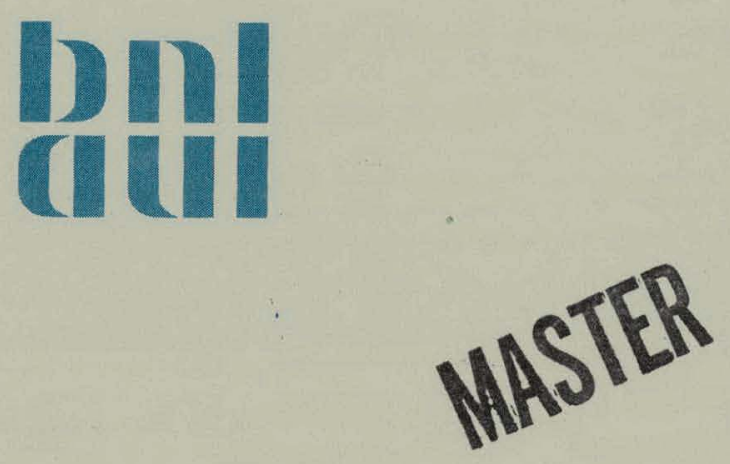

December 1977

ECONOMIC ANALYSIS DIVISION

NATIONAL CENTER FOR ANALYSIS OF ENERGY SYSTEMS

BROOKHAVEN NATIONAL LABORATORY ASSOCIATE.D UNIVERSITIES, INC. UNDER CONTRACT NO. EY-76-C-02-0016 WITH THE

UNITED STATES DEPARTMENT OF ENERGY 


\section{DISCLAIMER}

This report was prepared as an account of work sponsored by an agency of the United States Government. Neither the United States Government nor any agency Thereof, nor any of their employees, makes any warranty, express or implied, or assumes any legal liability or responsibility for the accuracy, completeness, or usefulness of any information, apparatus, product, or process disclosed, or represents that its use would not infringe privately owned rights. Reference herein to any specific commercial product, process, or service by trade name, trademark, manufacturer, or otherwise does not necessarily constitute or imply its endorsement, recommendation, or favoring by the United States Government or any agency thereof. The views and opinions of authors expressed herein do not necessarily state or reflect those of the United States Government or any agency thereof. 


\section{DISCLAIMER}

Portions of this document may be illegible in electronic image products. Images are produced from the best available original document. 


\title{
ESTIMATION OF SECTORAL PRICES IN THE BNL ENERGY INPUT-OUTPUT MODEL
}

\author{
Raymond G. Tessmer, JR., Paul Groncki, and Glenn W. Boyce, JR.
}

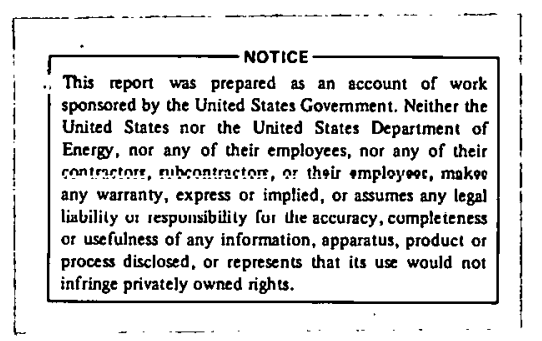

\section{BROOKHAVEN NATIONAL LABORATORY UPTON, NEW YORK 11973}




\section{NOTICE}

This report was prepared as an account of work sponsored by the United States Government. Neither the I Inited States nor the I Inited States Mepartment of Energy (DOE), nor any of their employees, nor any of their contractors, subcontractors, or their employees, makes any warranty, express or implied, or assumes any legal liability or responsibility for the accuracy, completeness or usefulness of any information, apparatus, product or process disclosed, or represents that its use would not infringe privately owned rights.

Printed in the United States of America Available from

National Technical Information Service

U.S. Department of Commerce 5285 Port Royal Road

Springfield, VA 22161

Price: Printed Copy $\$ 4.50$; Microfiche $\$ 3.00$ 


\begin{abstract}
Value added coefficients have been incorporated into Brookhaven's Energy Input-Output Model so that one can calculate the implicit price at which each sector sells its output to interindustry and final demand purchasers. Certain adjustments to historical 1967 data are required because of the unique structure of the model. Procedures are also described for projecting energy sector coefficients in future years that are consistent with exogenously specified energy prices.
\end{abstract}




\section{Table of Contents}

$\underline{\text { Page }}$

I. Introduction 1

II. Historical 1967 Prices . I

A. Description of BNL Model $1 . .1$

B: Sectoral Classification $\quad: \quad \cdot \quad 4$

C. Struatural Difference Detween BEA and BNL 4 Models

D. Normalization of Coefficients ' $\ldots$ ' ' ' . 5

E. Transactions Between Energy Supply Sectors 6

III. Projected 1985 Prices 11

A. Non-Energy Sector Coefficients 13

B. Determination of Energy Sector Prices 17

1. Coal 18

2. Crude Oil and Gas 18

3. Refined Oil Products 19

4. Pipeline Gas 1.9

5. Coal Combined Cycle Electric, Fossil 19

Electric, Light Water Reactor, High Temperature Gas Cooled Reactor, and Hydroelectric

6. Shale Oil, Coal Gasification and Coal 20 Liquefaction

C. Alignment of Coefficients to Desired Prices 20 


\section{Tables}

page

1. 1967 Energy Sector Outputs and Prices 8

2. Comparison of Major 1967 Fuel Transactions 8

3. Final Adjustment Coefficients for Energy sectors 8

4. 1967 Value Added Coefficients 12

5. 1967 I-O Prices 12

6. Annual Percent Change in Output Per Man Year for 1967- 14 $1976,1976-1985,1985-2000$

7. Calculation of Desired I-O Energy Prices : 21

8. 1985 Adjustment Factors for Major Fuel Transactions 21

9. Comparison of 1967 and 1985 Property Type Income Co- 23 efficients

10. 1985 Value Added Coefficients 24

11. 1985 I-O Prices 25

\section{Figures}

Page

1. I-O Units of Measure 2

2. Sectoral Classification of BNL Energy Input-Output 9 Model and Alignment, with Other Classification systems

3. Annual Percentage Changes in Output Per Man Year, 1967-1985 
I. Introduction

Value added coefficients have been incorporated in Brookhaven's Energy Input-Output Model (I-O). These describe sectoral payments for capital services, labor services, and indirect business taxes per unit of output. With these coefficients and the coefficient of production matrix, one can calculate the implicit price at which each sector sells its output to interindustry and final demand purchasers. This would be a trivial exercise for the Bureau of Economic Analysis (BEA) historical I-O tables in which all transactions are measured in dollars and all implicit prices are indexed at $\$ 1$. It becomes useful, however, with projected I-O tables for future years where one is interested in examining changes in productivity and relative prices over time.

Because the BNL model differs in structure from BEA I-O tables, some alterations are necessary in the normal procedure for estimating sectoral prices. These techniques are described first, and they are followed by techniques used in projections for future years.

II. Historical 1967 Prices

A. Description of BNL Model

The general structure and units of measure in the BNL I-O Model are depicted in.Figure 1. A general description of the model is presented in reference 1 . BEA data used in specifying the model is contained in reference 2 and energy data in reference 3. A listing of the BNL sectors and the correspondence with $B E A$ sectors is given in Figure 2.

Each column, j, of coefficients in the A matrix describes the interindustry purchases necessary to produce a unit 


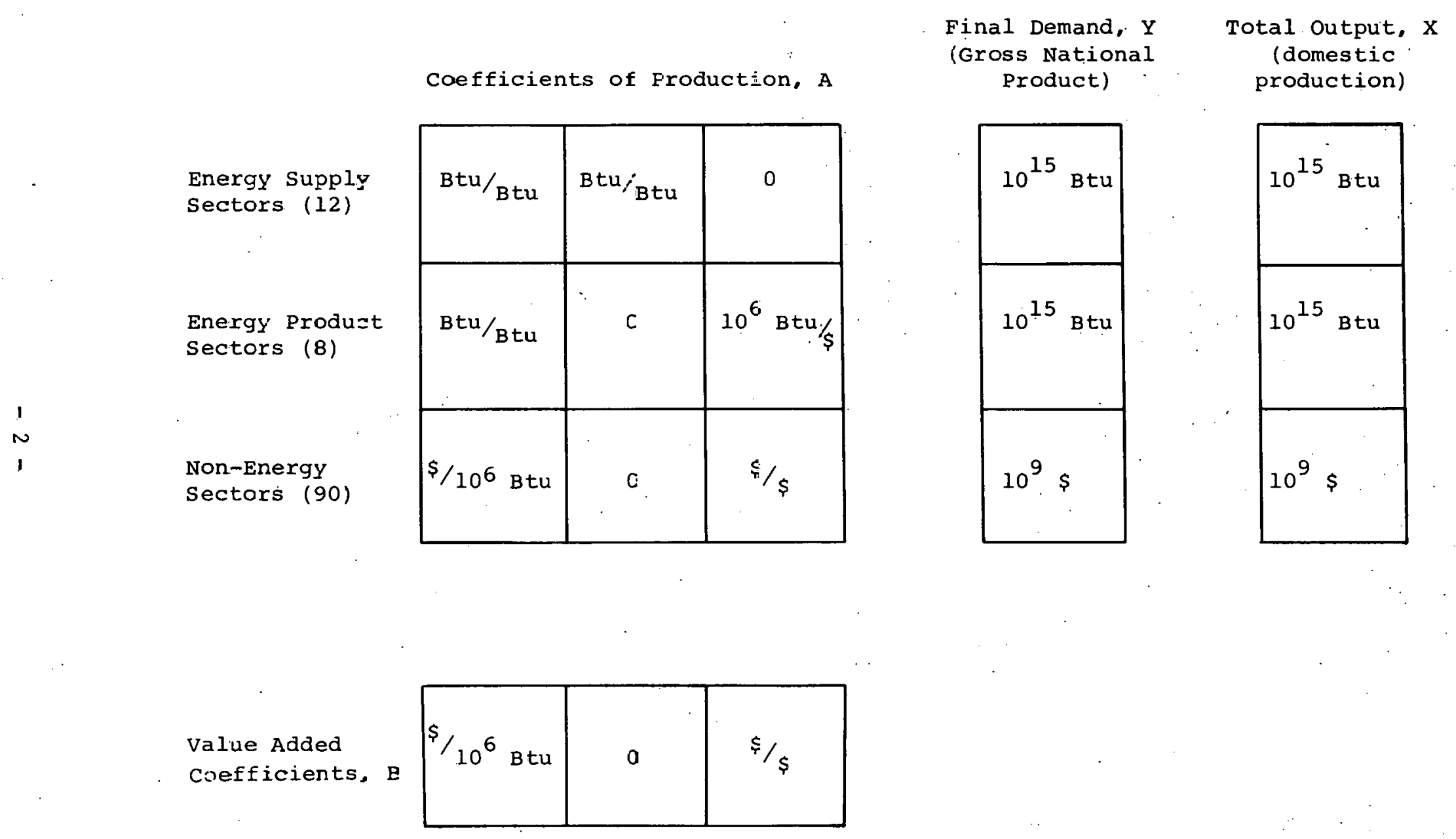

Fizure 1. I-0 units of measure. 
of output of sector $j$. The corresponding value added coefficients in column $j$ of the $B$ matrix represent primary factor purchases per unit of output of sector $j$. Three factors of production are employed - labor services, capital services (or property type income), and indirect business taxes. It is assumed that each sector sells its output to every interindustry sector and to each final demand purchaser at a single price, and that each primary factor is also purchased at a single price by every interindustry sector. Under this assumption, one can write a column equation for each sector which says that the value of interindustry purchases per unit output of sector $j$ plus the value of primary factor purchases per unit output of sector $j$ equals the selling price of sector j's output. The set of equations for all sectors can be expressed in matrix notation as,

$$
\begin{aligned}
& A^{T} P+B^{T} W=P \\
& \text { where } A=\text { coefficient of production matrix, } \\
& \text { j } \times j \\
& P=\text { vector of interindustry prices, } \\
& \text { j } \times 1 \\
& B=\text { value added coefficient matrix, } \\
& m \times j \\
& W=\text { vector of primary factor prices, } \\
& \mathrm{m} \times 1 \text {. }
\end{aligned}
$$

Given $A, B$ and $W$, this can be solved for interindustry prices, $P$,

$$
P=\left(I-A^{T}\right)^{-1} B_{W} \text {. }
$$

Since all primary factor purchases in the BNL model are expressed in terms of actual 1967. dollar transactions, each of the three factor prices, $w$, are $\$ 1$. The only task prior to solving equation (2) is to express the $B$ matrix in terms that are consistent with definitions and conventions used in the BNL model, as described below. 


\section{B. Sectoral classification}

Value added purchases in terms of the BEA 85-industry categories are presented in Table. 1 of reference 2 . They are disaggregated into three components: employee compensation (EC), indirect business taxes (IBT), and property-type income (PTI). Certain BNL model sectors are disaggregates of these sectors, however.* One must therefore use value added data for BEA 367-industry categories for these sectors which is published in reference 4. Because this detailed data is not disaggregated into the three value added components, it has been assumed that the proportional split is the same as that in its aggregate sectoral classification on an 85-industry basis.

C. Structural Difference Between BEA and BNL Models Sectoral purchases of transferred (competitive) imports are presented as an interindustry row by $B E A$ in their transactions table (sector $80 \mathrm{~B}$ ). The BNL model handles them as negative entries in one column of final demand (GNP). The $B N L$ entries are larger in absolute value than the $B E A$ row entries by the amount of their transportation and trade margins. BNL row transactions** for water transportation (BNL sector 92) and for. wholesale and retail trade (BNL sector 99) are therefore less than the corresponding BEA row transactions. The proportion by which trade and transportation margins on imported goods have reduced total output of these two sectors is thus used to scale down the BNL value added purchases for

* These are the new construction, maintenance and repair construction, refined oil products, utilities, transportation, federal government enterprises, and state/local government enterprise sectors, as noted in Figure 2.

** These are obtained by the multiplication $A_{i j} \cdot x_{j}$. 
sectors 92 and 99 from those documented by BEA.

Commodity Credit corporation column purchases (BEA sector 78.03) have been included in the Federal GovernmentOther column of final demand in the BNL model. The negative value added number for $B E A$ sector 78.03 is thus not included in the value added purchases of. BNL sector 107.

The BNL I-O model does not include two of the BEA sectors - 80A (directly allocated imports) and 83 (scrap, used and second-hand goods). These purchases must be accounted for in the BNL model, however, because equation 2 says that the total value of input purchases per unit output of each sector must add up to the selling price of that sector's output. This problem is corrected in the BNL model by adding an additional value added component (called "other value added") that represents sectoral purchases from BEA sectors $80 \mathrm{~A}$ and 83 .

Column $80 \mathrm{~A}$ has no entries in the BEA table, so this does not introduce a discrepancy between the two models. Column 83 (scrap) does have entries, however, and the BNL model has added them to the diagonal transactions for each row in which they appear. Although this does not bias total sales or production for each sector (the sum of interindustry and final demand purchases), it does bias upward the value of each sector's purchases. This bias is removed in the BNL model by adding another value added component (called "diagonal scrap") to the B matrix. The value of this component for any sector is equal to the negative of that sector's sales to sector 83 in the BEA I-O tahle.

D. Normalization of Coefficients

The five components of value added purchases must be normalized, or divided, by 1967 total output for each of the 
102 purchasing sectors.* Total outputs (domestic production) in the BNL model differ from the totals presented by BEA. BNL outputs are lower than those in BEA by the amount of competitive imports specified in the BNL import column of final demand. Additionally, outputs of the BNL energy sectors are expressed in physical units (Btu); so the value added coefficients for the energy sectors have units of $1967 \$ / 10^{6} \mathrm{Btu}$. The $1967 \mathrm{BNL}$ model energy sector outputs which are used for normalization are listed in Table 1.

Energy sector I-O prices for 1967 are also listed in Table 1. The coal price, $\$ \cdot 18 / 10^{6} \mathrm{Btu}$, is an average for lignite, bituminous and anthracite coals from Minerals Yearbook (10, pp. 20, 301, 380). Wellhead prices for the crude oil and gas sector (from the same source) are $\$ .16 / 10^{6}$ Btu for natural gas (10, p. 723) and $\$ .52 / 10^{6}$ Btu for crude petroleum (10; pp. 20 , 810). The average, weighted price for the crude sector is $\$ .35 / 10^{6}$ Btu. The price for the refined oil products sector, $\$ .97 / 10^{6}$ Btu, is averaged over Minerals Yearbook prices for gasoline, kerosene, jet fuel, distillate, and residual oils at various U.S. porls $(10$, pp. 868-71). For the plpeline gas sector, an average price of $\$ .61 / 10^{6}$ Btu for gas utilities over customers is used from Gas racts (11, p. 111). Electric sector prices are also based on utility sales and revenues for all customer types, as listed in Historical Statistics of the U.S. This price of $\$ 4.57 / 10^{6}$ Btu is based upon delivered Btu of energy, after transmission and distribution losses.

\section{E. Transactions Between Energy Supply Sectors}

Physical energy transactions between the energy sectors in the BNL model will not correspond to dollar transactions in the BEA table for several reasons. First, these

* The eight, dummy, energy product sectors, 13-20, have no value added purchases. 
sales will not in general be made at the same price as sales to other sectors in the economy. Secondly, the diagonal entries differ by definition. In the BEA model they represent sales between companies which are all classified within a single I-O sector. In the BNL model they are only an accounting method for Btu conversion losses: (say crude gas to pipeline quality gas), distribution losses; and transmission losses. In order to calculate correct sectoral prices in the BNL model it is therefore necessary to convert physical energy purchases by each of the first 12 sectors to the correct dollar purchases specified in the BEA I-O table.

With the implicit I-O energy prices listed in Table 1 one can express the BNL physical energy transactions in terms of dollars and compare them with BEA dollar transactions. The most important intersectoral fuel transactions are compared in Table 2 .

The disparity in the crude oil sales to the refined oil and pipeline gas sectors is a result of gas being very cheap relative to oil in 1967. The lower BEA dollar fuel sales to the electric sector primarily reflect the fact that fuel sales to utilities were at lower prices than fuel sales to other sectors.

The BNL modcl correats the problem with these five transactions in the following manner. The five A matrix coefficients for these transactions are simply multiplied by the ratios listed in Table 2 prior to calculating I-O prices in equation 2. A subprogram is incorporated to do this, as well as store the original A matrix coefficients so that the "true" physical values can be printed out at the end of the program. This subprogram also zeros the twelve diagonal "loss" coefficients before I-O prices are calculated. 
TAELE 1.

1967 Energy Sector Outputs and Prices

\begin{tabular}{|c|c|c|}
\hline sector & $\begin{array}{c}\text { Total output, } \\
10^{15} \text { Btu }\end{array}$ & $\begin{array}{l}\text { I-0 2rice, } \\
\text { s } / 10^{6} \text { Btu }\end{array}$ \\
\hline 1. coal. & 14.804 & .18 \\
\hline 2. Crude 0 il and Gas & 40.068 & .35 \\
\hline 6. Refined oil products. & 23.244 & .97 \\
\hline 7. Pipeline Gas & 18.355 & .61 \\
\hline 9. Fossil Electric & 3.362 & 4.57 \\
\hline 10. LWR Electric & 0.026 & 4.57 \\
\hline 12. Hydroelectric & 0.756 & 4.37 \\
\hline
\end{tabular}

TABLE 2

Comparison of Major 1967 Fuel Transactions, $10^{9} \$$

(1) BNL \$

(2) BEA $\$$

Ratio

Transaction Transaction (2) $\div$ (1)

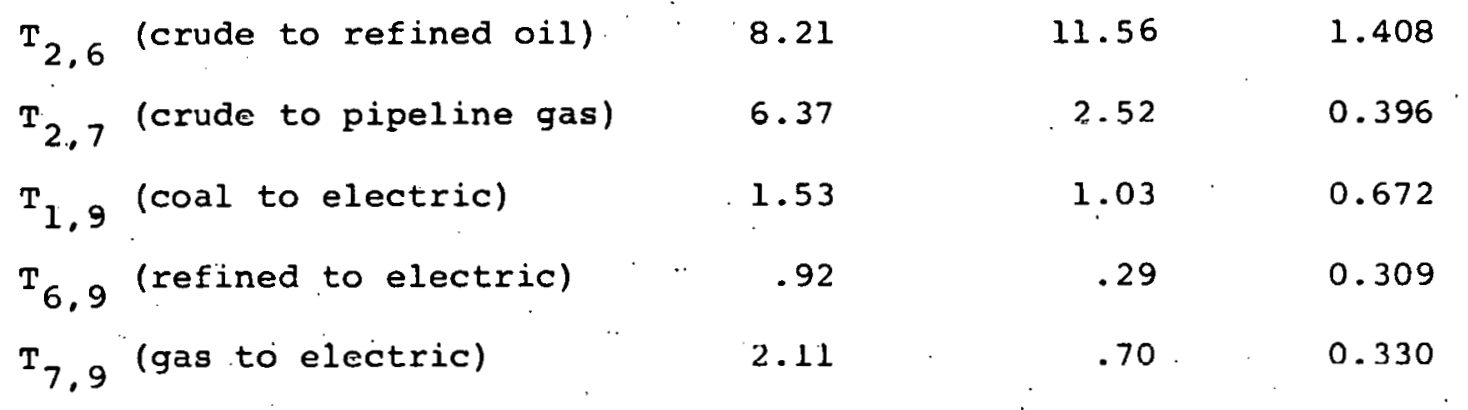

TABLE 3

Final Adjustment Coefficients for Energy sectors

Purchasing sector

1. Coal

2. Crude $0 i l$ and Gas

6. Refined Oil products

7. Pipeline Gas

9. Fossil Electric

10. LWR Electric

12. Hydroelectric
"Other Value Added" coefficient

$$
\begin{array}{r}
0.0 \\
.00537 \\
-.09146 \\
.11668 \\
.34963 \\
-.62454 \\
1.04075
\end{array}
$$




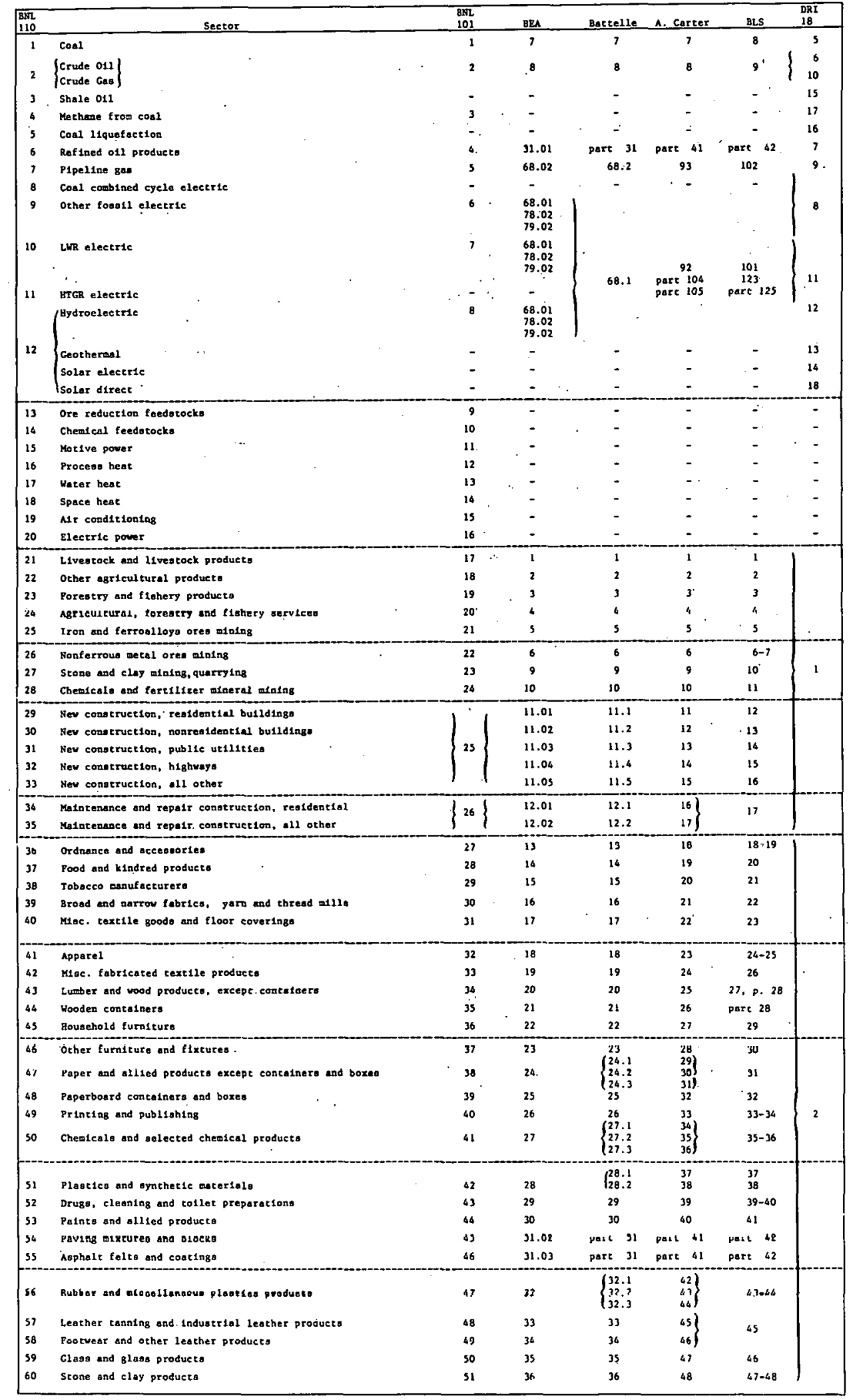

Figure 2. Sectoral classification of BNL energy inputoutput model and alignment with other classification systems. 


\begin{tabular}{|c|c|c|c|c|c|c|c|}
\hline $\begin{array}{l}\mathrm{BR} \\
110 \\
\end{array}$ & Sector & $\begin{array}{l}\text { BNI } \\
101 \\
\end{array}$ & $\underline{\mathrm{BPA}}$ & Batrelle & A. Carker & BLs. & $\begin{array}{l}\text { DRI } \\
18\end{array}$ \\
\hline 61 & Primaty 1ron and steel manufacturiag & 52 & 37 & 37 & 49 & $49-50$ & \\
\hline 62 & Primary nooferrous metala menufacturing & 53 & 38 & $\left\{\begin{array}{l}38.1 \\
38.2 \\
38.3\end{array}\right.$ & $\left.\begin{array}{r}50 \\
51 \\
52\end{array}\right\}$ & $51-57$ & \\
\hline 63 & Metal conteiners & 54 & 39 & $\begin{array}{l}138.3 \\
39\end{array}$ & 521 & 58 & \\
\hline 64 & Heating, plumbing and fabricaced atzuctural metal producta & 35 & 40 & 40 & 54 & $59-60$ & \\
\hline 65 & Screv mechine prod., bolte, nuts, etc. S metal stauplings & 56 & 41 & $\$ 1$ & 55 & 61 & \\
\hline 66 & Other fabrieated metal produets & 57 & 42 & 42 & 36 & 62. & \\
\hline 67 & Engines. and turbiney & 58 & 43 & 43 & 57 & 63 & \\
\hline 68 & Parm machlnery & 59 & 46 & 44 & 58 & 64 & \\
\hline 69 & Construct10s, mlaing, o1l fleld wachinery, equipment & 60 & 45 & 45 & 59 & 65 & \\
\hline 70 & Materials huadling machloery and equipment & 61 & 46 & 46 & 60 & 66 & \\
\hline 71 & Metalwork1ng maehinery and equiparat & 62 & 47 & 47 & 61 & 67 & \\
\hline 72 & Spec1al induetry wachinery and equipment & 63 & 48 & 48 & 62 & 68 & \\
\hline 73 & General Industr1al machinery and equiprear & 68 & 49 & 49 & 63 & 69 & \\
\hline 74 & Mach1ne ohop products & 65 & 50 & so & 64 & 70 & 2 \\
\hline 75 & Office, computing and accounting tachlnes & 66 & 51 & 51 & 65 & $71-72$ & \\
\hline 76 & Service Industry mechines & 67 & 32 & 52 & 66 & 73 & \\
\hline 77 & Elec. trans. o dete eq. o elec. Induatry epperatus & 68 & 33 & 153.2 & $\begin{array}{l}67 \\
68\end{array}$ & $\begin{array}{l}74 \\
75\end{array}$ & \\
\hline 78 & Household appliances & 69 & 54 & $\$ 4$ & 69 & 76 & \\
\hline 79 & Electric 11ght1ag and wiring equipoent & 70 & s5 & 35 & 70 & $n$ & \\
\hline 80 & Rod10, televiaion and commun1cations equipreat & 71 & 36 & 56 & $n$ & $78-80$ & \\
\hline 81 & Electron1c componente and accessories & 72 & 57 . & $\left\{\begin{array}{l}57.1 \\
57.2 \\
57.3\end{array}\right.$ & $\left.\begin{array}{l}72 \\
73 \\
76\end{array}\right\}$ & 81 & \\
\hline 82 & mocollendou eloc. meh1nety, squipment a supplics & 73 & 38 & 58 & 75 & 82 & \\
\hline 83 & Yotor vehicles and equipuent & 74 & 80 & 50 & .76 & B3 & \\
\hline 84 & Arerife and parts & 75 & 60 & 60 & 77 & 84 & \\
\hline 65 & Other traneportation equipsent & 76 & 61 & 61 & 78 & $85-87$ & \\
\hline 86 & Profeselonsl, selentif te o controlling lnst. 6 cupp. & $n 7$ & 62 & 62 & 79 & $88-89$ & \\
\hline 87 & Opticol, opthaloic, of photographic equip. is supp. & 78 & 63 & 63 & 81 & $90-91$ & \\
\hline 88 & Miscellaneous manufacturing & 79 & 64 & 64 & 82 & 92 & \\
\hline 89 & Ratirouds and related services & 80 & 65.01 & 65.1 & 83 & 93 & \\
\hline 90 & Locel, urban and interurban h1ghway peos. trasa. & 81 & $1 \begin{array}{l}65.02 \\
79.01\end{array}$ & 65.2 & $\begin{array}{c}84 \\
\text { part } 105\end{array}$ & $\begin{array}{c}94 \\
\text { pert } 125\end{array}$ & \\
\hline 91 & Motor freight transportation and werchousing & 82 & 65.03 & 65.3 & 85 & 95 & 3 \\
\hline 92 & Water transportation & ө3 & 65.04 & 65.8 & 86 & 96 & \\
\hline 23 & Alr ezaneporteston & 84 & 65.05 & 65.5 & 87 & 97 & \\
\hline 94 & Pipe 11ne trenaportation & 85 & 65.06 & 65.6 & 88 & 98 & \\
\hline 23 & Tranoporeation oorricoos & 86 & 65.07 & 65.7 & 89 & & \\
\hline 96 & Communcetiono except redio of television brodcenting & 87 & 66 & 66 & 90 & 99 & \\
\hline 97 & Redio and TV broadcaoting & 88 & 67 & 67 & 91 & 100 & \\
\hline 98 & Water and senitary oervices & 89 & 68.03 & 68.3 & 94 & 103 & \\
\hline is & Wholemale and recatl erede & 90 & 69 & 69 & 95 & $104-105$ & \\
\hline 100 & Plinance apd 1asurance & 91 & 70 & mo & 96 & $106-107$ & \\
\hline 101 & Rool ootate 4 rantel & 92 & 71 & 71 . & 97 & $108-109$ & \\
\hline 102 & Hotelo \& lodg1ng; pers. o tepalr serv.; except auto repalt & 93 & 72 & 72 & 98 & $110-111$ & \\
\hline 103 & Buelnicao antricos & $\$ 4$ & 13 & 3 & gy & $112-210$ & 4 \\
\hline 104 & Autombille repalr o servlces & 95 & 75 & 75 & 101 & 115 & \\
\hline 105 & Anusemeats & 96 & 76 & 76 & 102 & $116-117$ & \\
\hline 106 & Medical, edue. services o nouproflt last. & 97 & $n$ & 77 & 103 & $118-121$ & \\
\hline 107 & Pederal government enterprises & 98 & $\left\{\begin{array}{l}78.01 \\
78.04\end{array}\right.$ & - & part 104 & $\begin{array}{l}122 . \\
124\end{array}$ & \\
\hline 108 & State and Jutal governotut enterprises & 99 & 79.03 & - & pare 105 & pare 125 & \\
\hline 109 & Bubiness travel, entertaloment o gifts & 100 & 81 & - & 107 & 128 & \\
\hline 110 & off1ce oupplies & 101 & 82 & - & 108 & 129 & \\
\hline .. & Rosearith 6 dovalepeent & - & $74 \%$ & - & $\operatorname{lnn}$ & $=$ & \\
\hline- & Gross Imports & - & 80 & - & 106 & $126-127$ & \\
\hline- & Serap, used and second hand goods & - & .83 & - & 109 & 130 & \\
\hline- & Governmeat faduetry & - & 84 & - & - & 131 & \\
\hline- & Reat of vorid Industry & - & 85 & - & - & 132 & \\
\hline - & 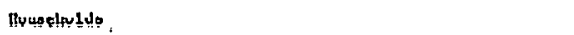 & . & B6 & - & - & 133 & \\
\hline - & Inventory valuation adjuatmeat & - & 87 & - & - & 134 & \\
\hline
\end{tabular}

QElisinated as a separate sector by bes in the 1963 and 1967 seuales.

- Coda: aNL 110 - Brookhoven Kat1onel Labotatory lin epetar verainn

BML 101 - Brootheven Natranel Labstatery !n! Becter varaton

BRA - Bureau of Econotilc Analygls, U.S. Dept. of Comerce

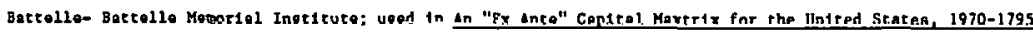

A.Carter- Professor Arn Carcer, Brande1s University

BLS - Bureau of Labor Stat1at1ca, U.S. Dept. of Labor

DRI 18 - Data Resources, Ine. 18 sector Interinduatry model

Figure 2 (Cont'd.). Sectoral classification of BNL energy input-output model and alignment with other classification systems. 
With the above adjustments one does still not obtain the desired energy sector prices because energy sector transactions on the diagonal are now zero in the price calculation program of the BNL model. By trial and error, coefficients have been added to the "other value added" row to obtain the desired energy prices. These coefficients are listed in Table 3.

If one now calculates BNL I-O prices after the above modifications one still does not come out with a price of $\$ 1.0$ for all non-energy sectors. This is primarily a result of fuel sales to non-energy sectors being in some cases at different prices from the "average" I-O prices. Adjustments to "other value added" purchases have therefore been made in certain nonenergy sectors to bring their calculated I-O price to within 5\% of the desired price of $\$ 1.0$. Sectors so adjusted are identified in Table 4 which tabulates the value added coefficients by component for all 110 sectors in the BNL model. Table 5 lists the final set of sectoral prices as calculated from equation 2, total value added purchases, and aggregated value added coefficients.

III. Projected 1985 Prices

Brookhaven's Energy Input-Output Model, when specified for a future planning year, can be used to estimate relative prices for the output of all 110 sectors in the economy. To do this one must first project the level and structure of Gross National product (a $110 \times 8$ matrix), the A matrix coefficients of production (a $110 \times 110$ matrix) and the value added coefficients (a 5 x 110 matrix).. Procedures for doing this and for controlling to a set of exogenously specified energy prices are described below. 
1967 Value Added Coefficients

$\left(\$ / 10^{6} \mathrm{Btu}, \$ / \$\right)$
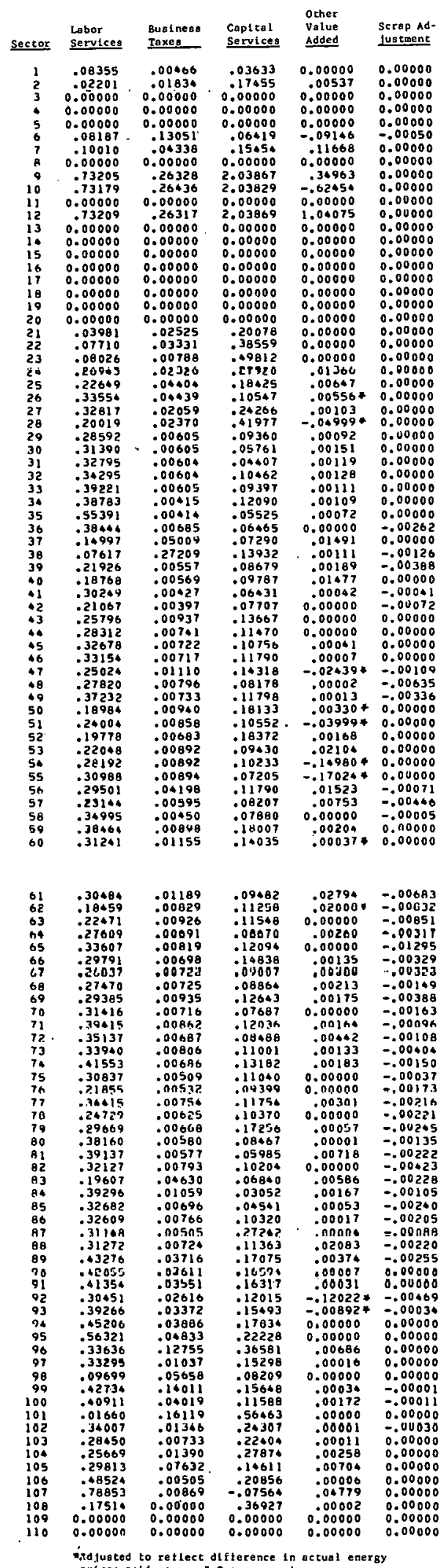

prised to retiect difterence in actur
I-0 Prices

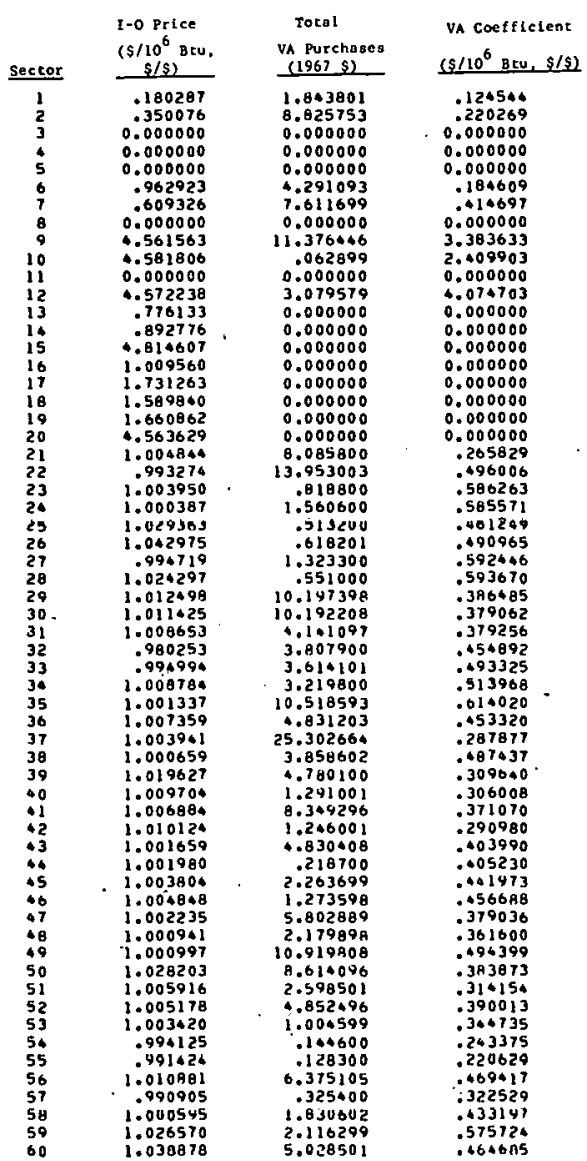

\begin{tabular}{|c|c|c|c|}
\hline 61 & 1.031702 & 13.022487 & .432662 \\
\hline 62 & 1.019632 & 5.934504 & .317211 \\
\hline 63 & 1.014990 & 1.141400 & .340936 \\
\hline 64 & 1.010853 &. .593900 & .369126 \\
\hline hs & loningni & 0,16 iny.3 & $-45+4 a 4$ \\
\hline 66 & 1.007426 & 5.493308 & .051332 \\
\hline 67 & 1.007369 & 1.370099 & .360302 \\
\hline 60 & 1.000670 & 1.000699 & : 371283 \\
\hline 69 & 1.008297 & 2.513402 &.+27502 \\
\hline 70 & 1.005181 & .996700 & .396563 \\
\hline 71 & 1.001471 & $\because .374299$ & $.523 \theta_{12}$ \\
\hline 12 & 1.002137 & 2.403001 & - Aantaba \\
\hline 73 & $1,00<\theta 29$ & 3.44 .3003 & $.05+757$ \\
\hline 76 & .995504 & 2.183299 & .554541 \\
\hline 75 & 1.003710 & 2.747603 & .423489 \\
\hline 76 & 1.006409 & 1.664199 & .316129 \\
\hline 7 & 1.004055 & .550901 & .470970 \\
\hline 78 & $1.0080 \mathrm{AB}$ & 1.430509 & .355031 \\
\hline 79 & 1.006360 & 1.916700 & .074038 \\
\hline 80 & 1.003211 & 7.789005 & -470733 \\
\hline $8 !$ & 1.006833 & 3.682298 & .661954 \\
\hline 82 & 1.008791 & 1.293100 & .427002 \\
\hline 83 & 1.009004 & 13.551500 & $.31+343$ \\
\hline 84 & 1.002654 & 9.485209 & .434688 \\
\hline 85 & 1.007201 & 2.874596 & .377311 \\
\hline $\begin{array}{l}86 \\
67\end{array}$ & 1.001209 & 2.613397 & .435063 \\
\hline $\begin{array}{l}87 \\
\text { A }\end{array}$ & 1.004380 & 2.678702 & .588118 \\
\hline $\begin{array}{l}\text { A R } \\
60\end{array}$ & $1.0 n 1623$ & 3,9317000 & , $4523 ?$ \\
\hline 89 & 1.017705 & 0.152203 & .641868 \\
\hline 90 & 1.005891 & 3.409005 & .622677 \\
\hline $\begin{array}{l}91 \\
91 \\
92\end{array}$ & $479+34$ & 111819790 & - 018540 \\
\hline $\begin{array}{l}92 \\
93\end{array}$ & $1.018 \phi_{1 z}$ & 1.548797 & $\begin{array}{r}325807 \\
572057\end{array}$ \\
\hline 93 & 1.018314 & 4.554902 & .572057 \\
\hline 94 & .974148 & .006101 & .664253 \\
\hline 95 & $1.000+71$ & $.8+8900$ & .833008 \\
\hline $\begin{array}{l}96 \\
97\end{array}$ & 1.000361 & 16.101612 & .036577 \\
\hline 97 & .999683 & 1.580400 & $-\$ 96454$ \\
\hline $\begin{array}{l}96 \\
99\end{array}$ & 1.010263 & .834700 & .235054 \\
\hline 99 & $1.000 \Delta 19$ & 117.368161 & $.72+? \geqslant 70$ \\
\hline 100 & 1.902666 & $26.97619 \mathrm{~b}$ & .566797 \\
\hline 101 & .993392 & 84.072781 & .742426 \\
\hline 102 & 1.015169 & 12.405990 & .596308 \\
\hline 103 & 1.002657 & 29.082093 & .515981 \\
\hline 104 & 1.001584 & 0.138800 & .551911 \\
\hline 105 & .998808 & 5.088097 & .527599 \\
\hline 106 & .998692 & 33.899897 & .698920 \\
\hline 107 & .999924 & 5.497802 & .769373 \\
\hline 108 & 1.007972 & 3.430502 & .564625 \\
\hline 109 & 1.009650 & 0.000000 & 0.000000 \\
\hline 110 & 1.003732 & 0.000000 & 0.000000 \\
\hline
\end{tabular}

PQICE INDEX $=1.00260$ 


\section{A. Non-Energy Sector Coefficients}

A 1985 A-matrix has been projected by the U.S. Bureau of Labor statistics. (5) This is specified in 1958 dollars, and they furnish sectoral deflators for the years 1958-1971 so that coefficients can be converted to other year dollars. For nonenergy purchases by non-energy sectors, BLS A-matrix coefficients are inflated to 1967 dollars and used directly. For energy product purchases by non-energy sectors, Brookhaven has made its own coefficient projections based on the 1967 estimates made by the center for Advanced computation and on trends in energy consumption projected by the Data Resources, Inc., Long Term Interindustry Model. (6)

For the value added coefficients it is assumed that those describing indirect business taxes, property type income, scrap adjustment, and other value added remain constant over time. All productivity changes are captured in the projections of employee compensation coefficients.

The productivity rates used to project the employee compensation coefficients from 1967 to 1985 were derived from estimates made by Almon ${ }^{(7)}$ and Bezdek ${ }^{(8)}$ for this period. They were judgementally adjusted based on information available for 1976. Annual percentage changes in output per constant hour man year for the periods 1967-1976, 1976-1985, and 1985-2000 appear in Table 6 . Figure 3 shows annual changes by sector for the 1967 to 1985 period. These productivity rates (R $1967-1985)$ were applied to the 1967 employee compensation coefficients $(\mathrm{EC} / \mathrm{X})$ in the following manner:

$$
\left(E C /{ }_{X}\right)_{1985}=\left(1+R_{1967-1985}\right)^{-18} \cdot\left(E C /{ }_{X}\right)_{1967^{\circ}}
$$

If the model is now run for 1985 using equation 2 and the 1985 data, the prices obtained for the energy sectors 1-12 
TABLE 6

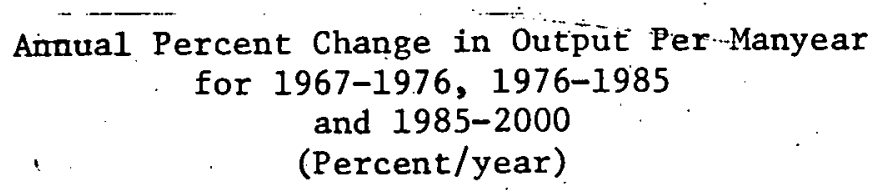

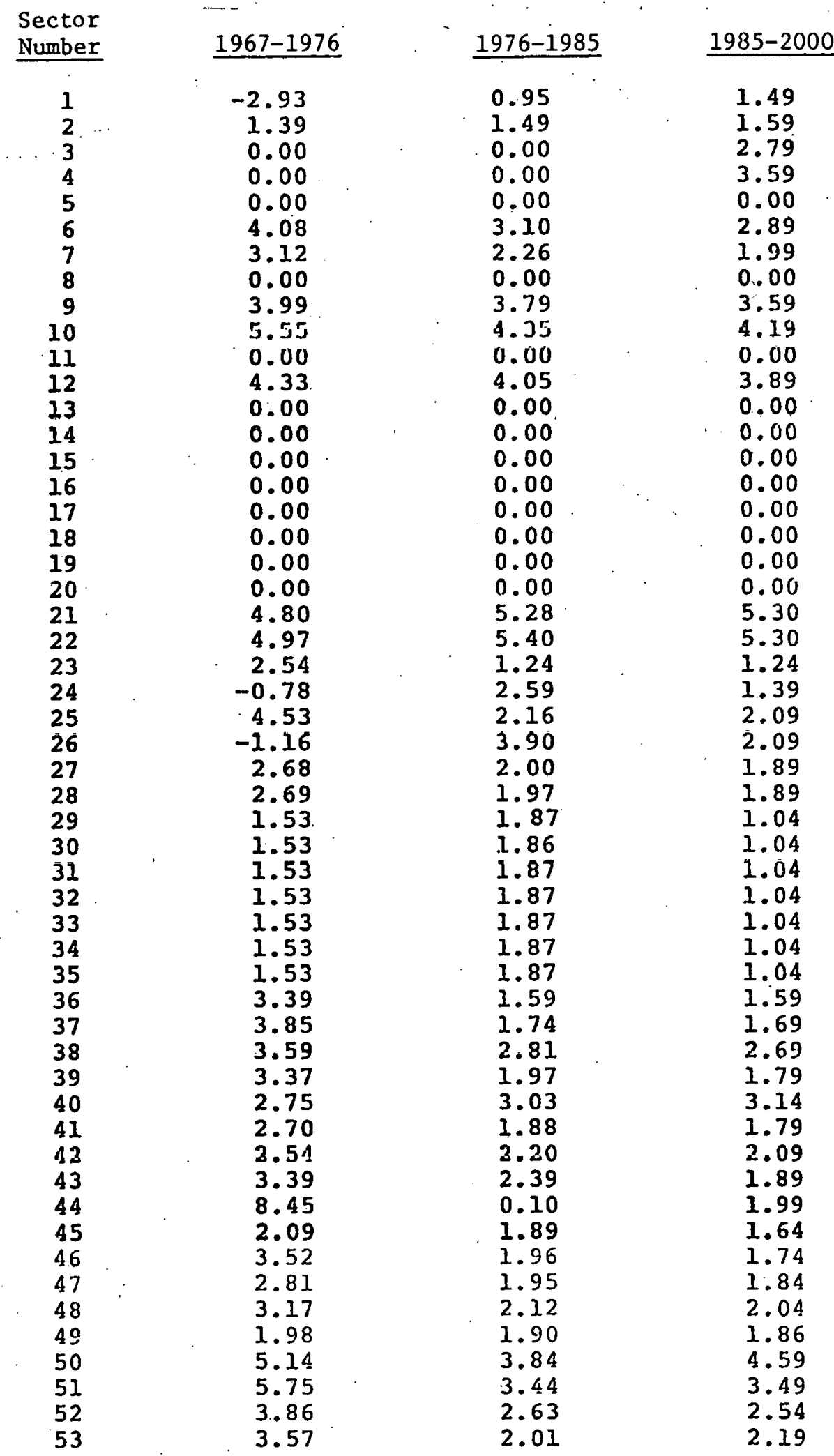


TABLE 6 (cont'd.)

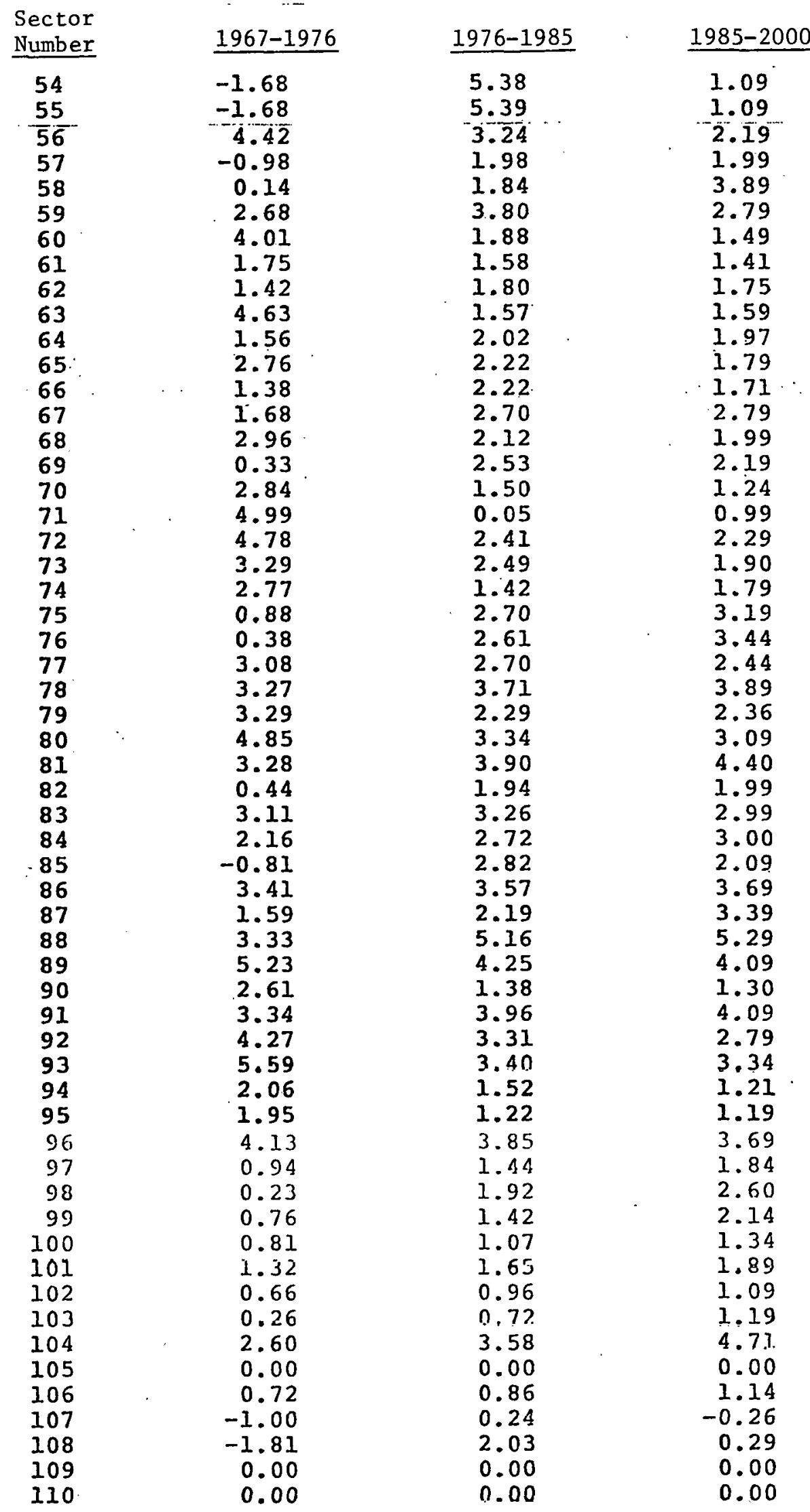



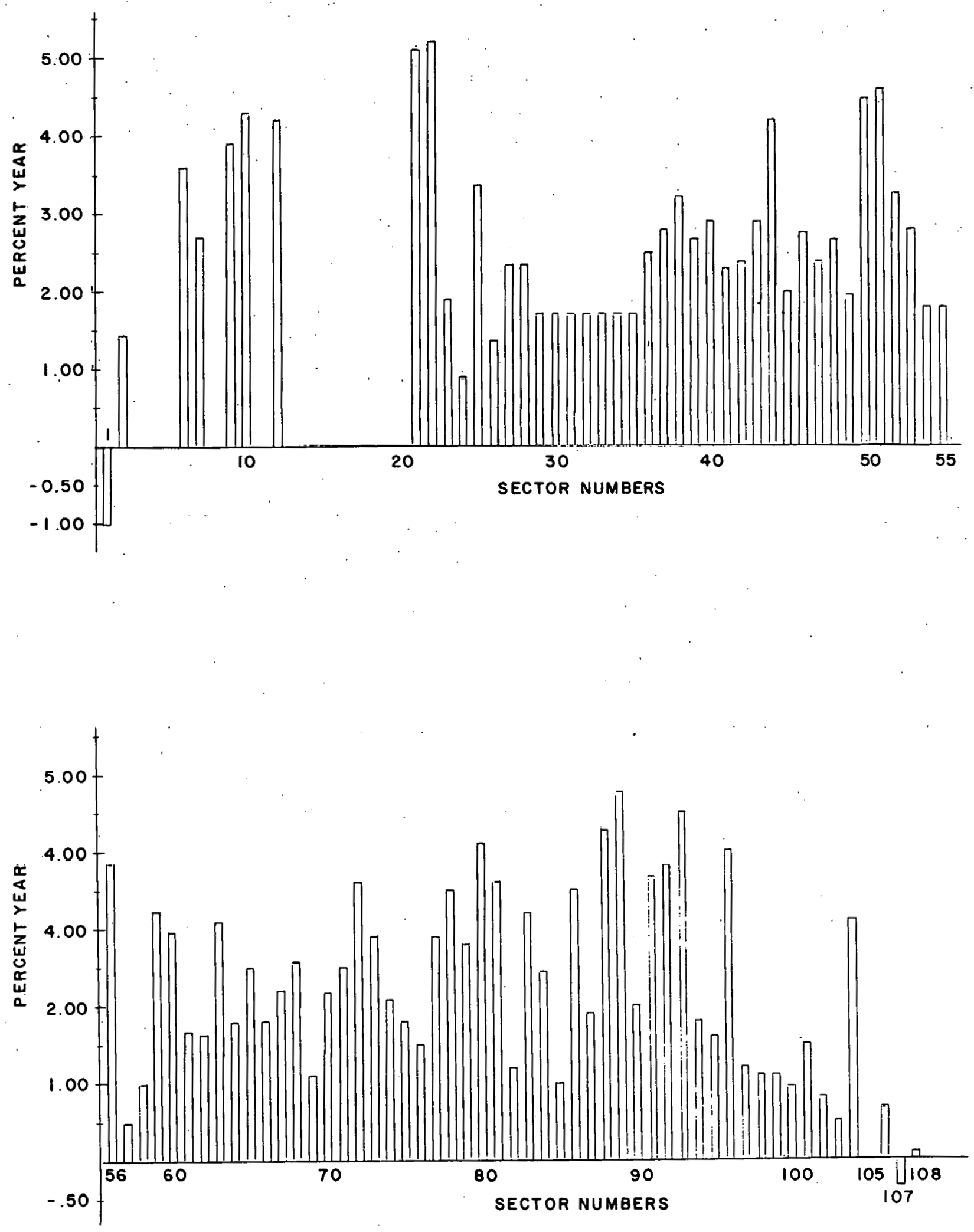

Figure 3. Annual percentage changes in output per manyear, 1967-1985. 
may not conform to exogenously specified prices. Several adjustments must be made to obtain the desired 1985 prices for sectors 1-12. These desired prices are discussed next, followed by the parameter changes which were necessary to obtain these prices.

\section{B. Determination of Energy Sector Prices}

In order to set up the model in terms of exogenously specified energy prices, one must first determine the desired I-O prices that you want equation 2 to calculate. This involved the following steps: '(1) deflating specified energy prices to 1967 dollars* to obtain the "real" 1985 energy price (in 67 \$) with respect to the "real" 1985 price of all other goods and services ( $\$ 1.0$ in $1967 \$)$, and (2) adjusting for productivity gains in the production of other goods and services. Because of aggregate productivity gains expected between 1967 and 1985, calculated I-O prices in (67 \$) of most non-energy goods and services will be lower in 1985 than in 1967. To maintain correct relative 1985 prices, energy prices must be reduced in proportion to the average reduction in the cost of non-energy goods and services.

For the second step, an aggregate price index** of non-energy goods and services is constructed for 1967 and the planning year, in this case 1985. This is computed with the solution prices to equation 2 and the vector of total sectoral outputs:

$$
{ }_{B I}{ }^{t}=\frac{\sum_{P_{j}^{t}} \cdot x_{j}^{t}}{\sum_{j} x_{j}^{t}} \text {, for } j=21-100 \text {, in year } t \text {. }
$$

* The following deflator is used: 1967-1975 $=1.586$ (Survey of current Business GNP deflator).

** C.E. Furguson's index of income change is employed. 
For 1967 this price index is 1.0, and for 1985 it is .878 in this example. The $1985 \mathrm{x}$ vector was estimated with a projected GNP ( $Y$ vector) according to the standard input-output equation,

$$
X=(I-A)^{-1} Y
$$

(Since non-energy prices for 1985 changed slightly as energy sector prices were adjusted, a 1985 price index was actually recalculated several times as energy prices were brought into alignment,) Now, qiven deflated enerqy prices for the corresponding I-O definitions, they are multiplied by $\mathrm{PI}{ }^{85} / \mathrm{PI}^{67}$ to obtain. the relative price that one wants the model to calculate. Calculation of desired I-O prices are discussed below using BNL estimates for a recent planning exercise as an example, first for conventional technologies and secondly for new technologies.

\section{Coal}

The 1985 BNL coal price is $\$ .64 / 10^{6}$ Btu (1967 $\$$ ) at the minemouth. This price must be multiplied by . 878 to find the relative coal price in 1967 dollars. $\$ .56 / 10^{\mathcal{G}} \mathrm{Btu}$, that should be calculated by the I-O price program. 'Since the price of coal was $\$ .18 / 10^{6}$ Btu in 1967, a significant decrease in this sector's productivity is presumed.

\section{Crude Oil and Gas}

Deflated 1985 prices assumed for crude oil and crude gas at the wellhead are, respectively, $\$ 1.34 / 10^{6} \mathrm{Btu}$ and $\$ 1.48 / 10^{6}$ Btu in 1967 dollars. The single sectoral price, weighted by their respective 1985 production levels, is $\$ 1.40 / 10^{6}$ Btu. Correcting for productivity change, the desired 1985 I-O price for crude oil and gas is $\$ 1.23 / 10^{6}$ Btu. (Individual prices that correspond to this aggregate I-O 
price are $\$ 1.18 / 10^{6}$ Btu of crude oil and $\$ 1.30 / 10^{6}$ Btu of crude gas.)

\section{Refined oil products}

The 1985 refined petroleum products price which is assumed is $\$ 1.79$ in 1967 dollars. This $\$ .45$ markup from crude oil is the same as the 1967 markup, and it is assumed that there is no aggregate change in productivity for the refined oil sector over this period. Correcting for productivity change (by multiplying by .878), the desired 1985 price for refined oil products is $\$ 1.57 / 10^{6}$ Btu.

\section{Pipeline Gas}

The 1985 assumed price for delivered pipeline gas is $\$ 1.93 / 10^{6} \mathrm{Btu}$. As with oil, it is assumed that there is no aggregate change in productivity for this sector between 1967 and 1985, and the 1967 markup of $\$ .45 / 10^{6}$ Btu over crude gas is assumed. Adjusting for productivity change in non-energy goods and services, the desired I-O price for pipeline gas is $\$ 1.70 / 10^{6}$ Btu.

5. Coal Combined Cycle Electric, Fossil Electric, Light Water Reactor, High Temperature Gas Cooled Reactor, and Hydroelectric

The 1985 price of delivered electricity for these sectors is obtained from solution of the Brookhaven Energy System optimization Model, $\$ 6.17 / 10^{6}$ Btu in 1967 dollars. This model (BESOM) which is linked to the I-O model brings in the detailed cost structure of the utility industry, the fuel mix, and the mix between base, intermediate and peak load demands for electric power. (1) Multiplying by the productivity factor of .878 then gives the desired 1985 I-O price of $\$ 5.42 / 10^{6}$ Btu for all electric sectors, with all outputs mea- 
sured in Btu of delivered electricity. A single price is used for all electric sectors to avoid bias in calculations of energy product prices.

\section{Shale oil, Coal Gasification and coal Lique- faction}

The prices for these fuels are tied to the desired I-O prices of crude oil and crude gas. The desired crude shale oil price of $\$ 1.50 / 10^{6}$ Btu is $10 \%$ above the crude oil price; so the desired I-O price of shale oil is $\$ 1.39 / 10^{6}$ Btu in 1967 dollars. Similarly, the assumed coal liquids price of $\$ 2.40 / 10^{6}$ Btu is $79 \%$ above the crude oil price; so the desired I-O price of coal liquids is $\$ 2.11 / 10^{6}$ Btu. Finally, the assumed coal gas price of $\$ 2.36 / 10^{6}$ Btu is $59 \%$ above the crude gas price; so the desired $I-O$ price of coal gas is $\$ 2.07 / 10^{6}$ Btu.

The method for calculating all twelve desired I-O energy prices is summarized in Table 7 .

\section{Alignment of Coefficients to Desired 1985 Prices}

As in 1967, the major transactions between the energy supply sectors must be adjusted to take into account the fact that these sales will not in general be made at the same price as sales to other sectors of the economy. In 1967, we were able to compare the BNL transactions values with the BEA values in order to make this adjustment. In 1985, however, it is not known what the values of these transactions should be and the values in Table 8 were judgementally chosen. These eight adjustment factors must be inserted into the price calculation program so that the corresponding A matrix coefficients are multiplied by these factors prior to calculating $I-O$ prices. In addition, coefficients for coal to coal liquids and coal to coal combined cycle electric generation were cal- 
TABLE 7

Calculation of Desired I-O Energy Prices

Sector

coal

crude oil

crude gas

shale oil

coal gas

coal liquids

refined oil

pipeline gas

coal combd. cycle

fossil electric

LWR electric

HTGR electric

hydroelectric
Measurement Unit

raw coal

crude

crude

syncrude

procsd. gas

syncrude

refinèd

delivered gas

dlva. elec.

dlvd. elec.

dlvd. elec.

dlvd. elec.

dlvd. elec.
Specified

Price, $67 \$ / 10^{6}$ Btu

$\mathrm{P}_{\mathbf{C}}$

$\mathbf{x}$

$\mathrm{P}$ co

$\mathrm{P}_{\mathrm{cg}}$

$\mathrm{P}_{\text {so }}$

$\mathrm{P}_{\mathbf{m}}$

P cl

Pro

P.pg

$P e^{* *}$
Desired I-O

Price, $67 \$ / 10^{6}$ Btu

PI* $=P_{C}^{I O}$

$\times \quad \mathrm{PI}=\mathrm{P}_{\mathrm{CO}}^{\mathrm{IO}}$

$\mathbf{x}$

$\mathrm{PI}=\mathrm{P}_{\mathrm{Cg}}^{\mathrm{IO}}$

$\mathrm{xP}_{\text {CO }}^{\mathrm{IO}} \div \mathrm{P}_{\text {cO }}=\mathrm{P}_{\text {so }}^{\text {IO }}$

$\mathrm{x}_{\mathrm{Cg}}^{\mathrm{IO}} \div \mathrm{P}_{\mathrm{Cg}}=\mathrm{P}_{\mathrm{m}}^{\mathrm{IO}}$

$\mathrm{xP}_{\mathrm{cO}} \div \mathrm{P}_{\mathrm{CO}}=\mathrm{P}_{\mathrm{Cl}}^{\mathrm{IO}}$

$\times \quad \mathrm{PI}=\mathrm{PIO}_{\text {ro }}^{\text {IO }}$

$\mathbf{x}$

$\mathrm{PI}=\mathrm{P}_{\mathrm{pg}}^{\mathrm{IO}}$

* Price index' for non-energy goods and services; approx. .878 for 1985/1967.

** Average price of electricity from BESOM solution.

\section{TABLE 8}

1985 Adjustment Factors for Major Fuel Transactions

$\begin{array}{llr}\mathrm{T}_{2,6} & \text { (crude to refined oil) } & .77 \\ \mathrm{~T}_{2,7} & \text { (crude to pipeline gas) } & .61 \\ \mathrm{~T}_{1,9} & \text { (coal to electric) } & .67 \\ \mathrm{~T}_{6,9} & \text { (refined to electric) } & .75 \\ \mathrm{~T}_{7,9} & \text { (pipeline gas to electric) } & .75 \\ \mathrm{~T}_{3,6} & \text { (shale to refined) } & .77 \\ \mathrm{~T}_{4,7} & \text { (coal gas to pipeline gas) } & .61 \\ \mathrm{~T}_{5,6} & \text { (coal liquids to refined) } & .77\end{array}$


culated from. BESOM and inserted in the $A$ matrix so that prices could be estimated correctly for these technologies, even though their output levels were zero in the 1985 example. In order to obtain the desired prices discussed above, the Property-Type Income (PTI) coefficients for the energy supply sectors are adjusted until the desired-prices are obtained. The 1967 PTI coefficients and the 1985 PTI coefficients are compared in Table 9. All other value added coefficients for the energy sectors are unchanged from their 1967 values.

Table 10 shows the value added coefficients for all 110 sectors of the BNL model and Table 11 shows the final set of sectoral prices as calculated from equation 2 for 1985. If one wishes to set up the model for a different set of 1985 energy prices, it is necessary to first ask what factors are causing the difference in energy prices from the base case. The reasons then provide a basis for changing $A$ matrix and value added coefficients in the alignment process. A shift toward greater stripmining, for example, would be reflected through certain. A matrix changes in the coal column and changes in the property type income and employee compensation coefficients. Further, changes in government tax rates can be reflected in the indirect business tax coefficients. 
TABLE 9

$\begin{array}{lcr}\begin{array}{l}\text { Comparison of } 1967 \text { and } 1985 \\ \text { Income coefficients } \\ \left(\$ / 10^{6} \text { BTU }\right)\end{array} & \text { Type } \\ \text { coal } & .036 & .217 \\ \text { crude oil and gas } & .175 & 1.038 \\ \text { shale oil } & -- & 1.045 \\ \text { coal gas } & -- & 1.134 \\ \text { coal liquids } & -- & .937 \\ \text { refined oil } & .064 & .064 \\ \text { pipeline gas } & .155 & .155 \\ \text { coal combd. cycle elec. } & -- & 3.108 \\ \text { fossil electric } & 2.039 & 2.635 \\ \text { LWR electric } & 2.039 & 2.150 \\ \text { HTGR electric } & -- & 3.100 \\ \text { hydroelectric } & 2.039 & 1.714\end{array}$


Table 10

1985 Value Added Coefficients

(1967 \$/106 Btu, \$/\$)

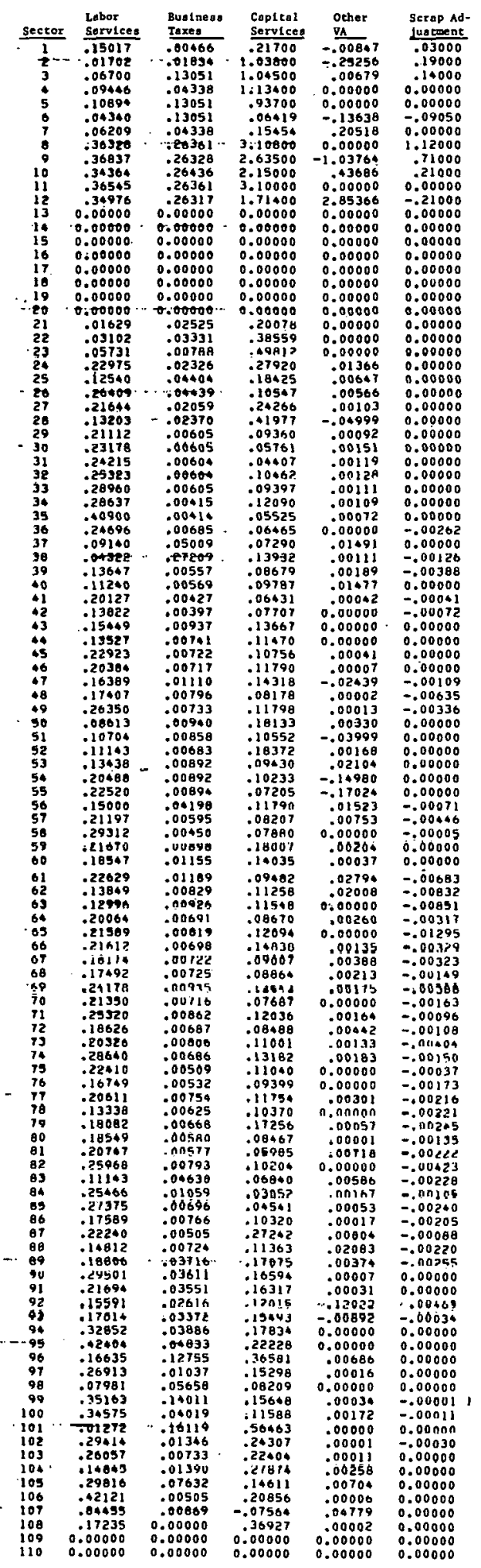


Table 11 .

1985 I-0 Prices

\begin{tabular}{|c|c|c|c|c|c|c|c|}
\hline Sector & $\begin{array}{r}1-0 \text { Price } \\
\left(s / 10^{6} \mathrm{gtu}, s / s\right)\end{array}$ & $\begin{array}{c}\text { VA Purchases } \\
(1967 \$ 1)-\end{array}$ & $\begin{array}{l}\text { VA Coefficients } \\
\left(s / 10^{6} \mathrm{Btu}, \quad s / s\right)\end{array}$ & Sector & $\begin{array}{c}I-0 \text { Price } \\
\left(s / 10^{6} \text { Btu, } s / s\right)\end{array}$ & $\begin{array}{c}\text { VA Purchases } \\
\text { (1967 \$s) }\end{array}$ & $\begin{array}{l}\text { VA cogfficients } \\
\left(S / 10^{6} \text { Btu, } S / S\right)\end{array}$ \\
\hline 1 & .556666 & 8.527281 & .393359 & 56 & .807947 & 8.726616 & .324410 \\
\hline 2 & 1.221125 & 42.326566 & 1.010808 & 57 & .912231 & .378458 & .303060 \\
\hline 3 & 1.389920 & .417540 & 1.389295 & 58 & .873745 & 1.758786 & .376370 \\
\hline $4 \cdots$ & 2.074875 & .265813 & 1.271835 & 59 & .855311 & 2.683872 & .407785 \\
\hline 5. & 2.110378 & 0.000000 & 0.000000 & 60 & .920684 & 6.934955 & .337747 \\
\hline 6 & 1.590923 & .400611 & .011214 & 61 & .941540 & 20.026623 & .354109 \\
\hline 7 & 1.713821 & 8.288754 & .465186 & 62 & .957327 & 10.855559 & .271112 \\
\hline 8 & 6.204063 & 0.000000 & 0.000000 & 63 & .854420 & 1.419578 & .246182 \\
\hline 9 & 5.427907 & 20.254657 & 2.939014 & 64 & .869608 & 7.726779 & .293677 \\
\hline 10 & 5.419400 & 9.254337 & 3.404857 & 65 & .833956 & 5. 305999 & .332066 \\
\hline 11 & 3.777156 & 0.000000 & 0.000000 & 66 & .871954 & 8.592424 & .369536 \\
\hline 12 & 5.417436 & 7.119909 & 4.970595 & 67 & .836616 & 2.374897 & .279670 \\
\hline 13 & 2.331113 & 0.000000 & 0.000000 & 68 & .926643 & 1.475864 & .271448 \\
\hline 14 & 1.578291 & 0.000000 & 0.000000 & 69 & .886405 & 3.692585 & .375440 \\
\hline 15 & 6.120090 & 0.000000 & 0.000000 & 70 & .821911 & 1.670048 & .295900 \\
\hline 16 & 3.438240 & 0.000000 & 0.000000 & 71 & .797058 & 4.596747 & .382860 \\
\hline 17 & 3.948706 & 0.000000 & 0.000000 & 72 & .758225 & 2.815554 & .281352 \\
\hline 18 & 3.498929 & 0.000000 & 0.000000 & 73 & .798699 & 4.217924 & .318623 \\
\hline 19 & 1.505854 & 0.000000 & 0.000000 & 74 & .018607 & 2.653384 & .425407 \\
\hline 20 & 5.584859 & 0.000000 & 0.000000 & 75 & .820922 & 5.089030 & .339218 \\
\hline 21 & .914037 & 12.291726 & .242313 & 76 & .853908 & 2.846899 & .265070 \\
\hline 22 & .914130 & 20.437671 & .449921 & 77 & .794790 & 5.714161 & .332031 \\
\hline 23 & .946810 & 1.899460 & .563307 & 78 & .809908 & 2.021759 & .241128 \\
\hline 24 & .920355 & 2.281691 & .545877 & 79 & .826394 & 3.057132 & .358273 \\
\hline 25 & .933511 & 1.051892 & .360156 & 80 & .697498 & 6.879829 & .274627 \\
\hline 26 & .969434 & 1.277916 & .419611 & 81 & .730725 & 3.083559 & .278045 \\
\hline 27 & .886477 & 1.903473 & .480721 & $\theta 2$ & .879273 & 1.952606 & .365419 \\
\hline 28 & 1.034226 & .889223 & .525519 & 83 & .816331 & 19.682601 & .229704 \\
\hline 29 & .864306 & 13.425838 & .311684 & 84 & .763052 & 5.676816 & .296387 \\
\hline 30 & .858529 & 19.088026 & .296942 & 85 & .872976 & 5.723497 & .324240 \\
\hline 31 & .858915 & 9.131177 & .293459 & 86 & .762481 & 2.752403 & .284863 \\
\hline 32 & .840754 & 2.316304 & .365172 & 87 & .867684 & 4.168745 & .499032 \\
\hline 33 & .841681 & 3.325569 & .390718 & 80 & .761797 & 5.046531 & .287625 \\
\hline 34 & .855399 & 4.836381 & .412505 & 89 & .733435 & 9.523890 & .397170 \\
\hline 35 & .017226 & 14.912234 & .469109 & 90 & .841659 & 3.972853 & .497141 \\
\hline 36 & .780157 & 2.253185 & .315841 & 91 & .728946 & 13.811430 & .415941 \\
\hline 37 & .873298 & 32.676724 & .229308 & 92 & .819483 & 1.459215 & .177306 \\
\hline 38 & .924974 & 4.481250 & .454479 & 93 & .793221 & 5.718230 & .357529 \\
\hline 39 & .854952 & 6.099558 & .226850 & 94 & .849113 & .861888 & .545714 \\
\hline 40 & .844049 & 1.842465 & .230728 & 95 & .844427 & 1.794800 & .694644 \\
\hline 41 & .803620 & 9.786916 & .269851 & 96 & .813606 & 27.292223 & .666572 \\
\hline 42 & .827944 & 1.636411 & .218526 & 97 & .907181 & 2.568763 & .432632 \\
\hline 43 & .829623 & 7.203975 & .300523 & 98 & .964672 & 1.193263 & .218470 \\
\hline 44 & .762677 & .235436 & .257372 & 99 & 907242 & 195.343915 & .648555 \\
\hline 45 & .825704 & 2.865716 & .344428 & 100 & .901485 & 45.262413 & .503431 \\
\hline 46 & .803095 & 1.578547 & .328987 & 101 & .963368 & 158.759641 & .738547 \\
\hline 47 & .905873 & 9.091883 & .292686 & 102 & $\because 941203$ & 19.318484 & .550379 \\
\hline 48 & .034272 & 2.842266 & .257472 & 103 & .918468 & 50.245762 & .492049 \\
\hline 49 & .838769 & 15.257573 & .385574 & 104 & .837360 & 10.909700 & .443671 \\
\hline 50 & .984745 & 13.079827 & .280156 & 105 & .973530 & 7.876714 & .527631 \\
\hline 51 & .074457 & 3.005396 & .181154 & 106 & .916613 & 64.176126 & .634886 \\
\hline 52 & $\ldots .859616$ & 9.123507 & .303658 & 107 & 1.024175 & 11.906039 & .825390 \\
\hline 53 & -.864414 & 1.377828 & .258632 & 108 & .968342 & 5.959573 & .541630 \\
\hline 54 & 1.187365 & .146999 & .166328 & 109 & .855805 & 0. & 0.000000 \\
\hline 55 & 1.104601 & .150726 & .135950 & 110 & .845763 & 0.000000 & 0.000000 \\
\hline
\end{tabular}




\section{References}

1. Behling, D.J., W. Marcuse, M. Swift and R.G. Tessmer, A Two-Level Iterative Model for Estimating Inter-Fuel Substitution Effects, BNL 19863 (July, 1975).

2. Bureau of Economic Analysis, U.S. Department of Commerce, The Input-Outpit Structure of the U.S. Economy: 1967, Sur. Cur. Bus., 54, No. 2, 24-56 (1974).

3. Knecht, R.L. and C.W. Bullard, End Uses of Energy in the U.S. Eoonomy, 1967, Center for Advanced Computation, University of Illinois at Urbana-Champaign, CAC Document No. 145 (September, 1975, rev.).

4. Bureau of Economic Analysis, U.S. Department of Commerce, Input-Output Structure of the U.S. Economy: 1967, Vol. I (1974).

5. Bureau of Labor Statistics, U.S. Department of Labor, 134-Order 1985 Input-Output Forecasts and 134-Order Deflators for the Years 1958-1971, unpublished, data tapes available from B.L.S., Washington, D.C.

6. Dullien, R.C., E.A. Hudson, B.S. Bernanke and D.N. Jorgenson, The Data Resources, Inc. Long-Term Interindustry Transactions Model: Theory and Use, Data Resources, Inc., Cambridge, Massachusetts (September, 1976).

7. Almon, C., M.B. Buckler, L.M. Horwitz and T.C. Reimbold, 1973-1985 in Figures, implement to "1985: Interindustry Forecasts of the American Economy", Lexington Books, Lexington, Massachusetts (1974).

8. Bezdek, R.H., Long-Range Forecasting of Manpower Requirements - Theory and Applications, Institute of Electrical and Electronics Engineers, New York (1974).

9. Office of Planning, Analysis and Evaluation, U.S. ERDA, Analysis of Alternate Energy Futures, mimeo, (February 4, 1977).

10. Bureau of Mines, U.S. Department of the Interior, 1968 Minerals Yearbook, V. 1, Washington, D.C. (1970).

11. American Gas Association, 1974 Gas Facts, Arlington, Virginia (1975). 